\title{
Ethnologies
}

\section{The Social Poetics of the Red River Jig in Alberta and Beyond Meaningful Heritage and Emerging Performance}

\section{Sarah Quick}

Volume 30, numéro 1, 2008

Danse au Canada

Dance in Canada

URI : https://id.erudit.org/iderudit/018836ar

DOI : https://doi.org/10.7202/018836ar

Aller au sommaire du numéro

\section{Éditeur(s)}

Association Canadienne d'Ethnologie et de Folklore

ISSN

1481-5974 (imprimé)

1708-0401 (numérique)

Découvrir la revue

Citer cet article

Quick, S. (2008). The Social Poetics of the Red River Jig in Alberta and Beyond: Meaningful Heritage and Emerging Performance. Ethnologies, 30(1), 77-101. https://doi.org/10.7202/018836ar
Résumé de l'article

La gigue de la Rivière Rouge est une mélodie jouée au violon ainsi qu'une danse qui ont une résonance particulière pour les Premières Nations et les Métis du nord et de l'ouest du Canada. Je m'intéresse ici à la pratique de ce modèle de danse dans différents cadres temporels et spatiaux. Cet article fait partie d'un projet plus vaste dans lequel j'analyse le lien entre l'identité, la représentation et le patrimoine métis en utilisant le concept de " poétique sociale » de Michael Herzfeld (2005) pour évaluer la gigue de la Rivière Rouge non seulement en tant que forme représentative du patrimoine métis mais encore comme une forme performative fruit de l'interaction sociale. En premier lieu, je retrace ici sa mise en scène à travers le temps avant de décrire sa forme et son mode d'apprentissage dans des contextes contemporains en Alberta et dans l'ouest canadien plus généralement. Enfin, j'analyse la gigue de la Rivière Rouge, ou certains de ses aspects, telle qu'elle émerge dans d'autres danses ainsi que dans d'autres contextes performatifs au-delà des frontières catégoriques de la musique et de la danse, afin de considérer les poétiques sociales de la gigue de la Rivière Rouge à l'intérieur de sphères de pratiques plus vastes.
Ce document est protégé par la loi sur le droit d'auteur. L'utilisation des services d'Érudit (y compris la reproduction) est assujettie à sa politique d'utilisation que vous pouvez consulter en ligne.

https://apropos.erudit.org/fr/usagers/politique-dutilisation/ 


\section{The Social Poetics of the Red River Jig in Alberta ANd Beyond

\author{
Meaningful Heritage and Emerging Performance
}

\section{Sarah Quick \\ Indiana University}

The Red River Jig is a fiddle tune and a dance form that have particular resonance for First Nations and Métis peoples in Northern and Western Canada. Here I follow the dance form's practice across diverse settings in time and space; and although dance is the focus of this article, I view the Red River Jig dance movements as intimately tied with its musical form. Gertrude Kurath's early observation that music and dance are interdependent and "merit further study of combined disciplines" applies here as well (1957: 10). This article is a part of a larger project in which I am analyzing the nexus of Métis identity, performance, and heritage; and, as in my larger project, I use Michael Herzfeld's concept of "social poetics" (2005) to gauge the Red River Jig not only as a representative form of Métis heritage, but as a performative form that emerges in social interaction.

Similar to others, I find a Peircian approach to semiotics most effective in exploring how music/dance are related with belief and social identity (Ness 1987; Turino 2001; Wolf 2006). The Red River Jig's mythos for many is that it links to an earlier time and place. For many Métis the Red River Jig is an indexical icon - providing living evidence of a thriving, unique, and ancient Métis culture. Its very namesake ties

1. The research for this paper would not haven been possible without the generous funding from the Canadian Studies Program's Graduate Student Fellowship and the Committee and Institutional Cooperation Graduate Student Fellowship. I also appreciate the helpful and insightful commentary from the anonymous reviewer. 
it to the Red River days, a spatiotemporal conceptualization that is also indexical of nineteenth century Métis cultural life ways and historical struggles. Its continued performance over a century later in the face of marginalization and diaspora creates an evocative symbol of survival. Métis culture has not been forgotten, and sustaining or recuperating the Red River Jig's vitality may be viewed as an urgent matter due to its significance as cultural heritage to contemporary Métis. Further, besides the prevalence of these kinds of associations between the Red River Jig and a specific narrative of a nineteenth century Métis cultural heritage, I am interested in the actions of contemporary performers that further stretch the Red River Jig's performative features as well as the symbolic associations that the Red River Jig may evoke.

This analysis stems from ethnographic and archival research during several summers since 2000 as well as a longer eight-month study (20023 ) in Edmonton, Alberta. Although Edmonton has generally been my primary base of research, I have travelled to several heritage events and festivals across the Prairie Provinces and British Columbia as well as Montana and North Dakota. Contemporary performers, politicians, and other cultural producers do the same, traveling especially in the summers to heritage events and/or political meetings, and some at quite extensive distances. While my study situates Métis life in Edmonton to some degree, it is more a study of the many venues interconnected by their virtue of bringing Métis (and others) together for heritage performance. Besides observing and often video-recording performances in these settings, I have participated as a learning fiddler and dancer in fiddle and dance workshops and regularly meeting classes. I also consulted performers one on one, asking them about their past experience as performers as well as about their understanding of the intricacies and aesthetics of these music/dance forms now embraced as Métis heritage. Exactly who identifies as Métis has evolved to become a complex sociopolitical terrain affected by historical and legal circumstances; the boundaries between First Nations and Métis peoples are particularly complicated and blurred due to intermarriage and changing provincial and federal policies. Although in contemporary public discourse the Red River Jig is often primarily associated with Métis peoples, Red River Jig performers (fiddlers and dancers) have historically included and still include people who identify as First Nations, French Canadian, and beyond. 


\section{A Chronicle of the Red River Jig in Alberta Practice}

Many accounts of nineteenth century life point to the popularity of fiddle dances for Native peoples, but the earliest published source I found referencing the Red River Jig specifically is "Dot It Down:" A Story of Life in the North-West. Here Alexander Begg, who as a journalist moved to the Red River settlement in 1867, wrote a fictionalized version of settlement activities in which he included a description of the Red River Jig as a dance for couples where "[a] gentleman leads a lady to the middle of the floor and at the sound of the fiddle the pair begin to dance to each other in a regular break-down manner" (Begg 1871: 279). However, in 1915, Joseph F. Dion found evidence of the Red River Jig's performance in the 1830 s as a common dance form in northern Alberta, when he recorded his wife's grandmother's remembrances of "dancing in the old days" as a young girl living west of Lesser Slake Lake near today's Grouard, Alberta. Mrs. Cunningham, whose French Canadian father came to the region to work in the fur trade, was in her late eighties at the time Dion recorded her recollections; she noted the Red River Jig as one dance among many to which her older brother provided accompaniment.

His only instrument: a tin pan, while he sang the tunes and kept time with his feet. Some of the young men could whistle the different tunes (Dion 1915).

Cunningham's family, like many other mixed-European and Native families in Alberta, later moved south to Lac Ste. Anne in the 1840s to live near the newly established mission, and here Mrs. Cunningham fondly remembered attending her first dance accompanied by a fiddle.

The Red River Jig continued to enjoy popularity in the late nineteenth century, its practice widespread via the extensive networks of the fur trade (Dion 1979: 82-83, 120; Mair 1908: 74-5; Mishler 1993: 16-22; Randall 1942: 15-7). Besides being performed by a male and female spaced apart, some sources also describe the Red River Jig as competitive challenges between young men showing off their stepping prowess (McKenzie 1921: 52; Dion 1979: 84); these descriptions are similar to what contemporary consultants remember of it as the only dance featuring only two dancers, either a male and a female or two competing males (see also Dorion-Paquin and Smith 2002: 18-19). In its early practice, the Red River Jig appears as a favourite among many fiddle dance forms performed at festive gatherings for entertainment 
and socializing as well as the marking of special events such as weddings and New Year's celebrations (Begg 1871: 279; Dion 1979: 120; Podruchny 2006: 176-181; Steele 1915: 85). Within the fur trade system, these dance festivities became a common practice, even another negotiating tool that the chief factors and fur trade clerks used towards their employees and those Aboriginal peoples they traded with along with the distribution of alcohol and gifts (McKenzie 1921: 52; Podruchny 2006: 176-190; Simpson 1938: 72, 77, 99).

At the turn of the century, while the Red River Jig remained everpresent in the social occasions of many Alberta Native peoples, it also appeared as an exhibition dance in non-Native settings, and here the Red River Jig acquired an additional valence as a nostalgic artifact indexing the earlier fur trading and frontier days. For example, at the turn of the century in Edmonton and in the 1920s in Calgary, Old Timers' associations formed in order to celebrate past exploits and sponsored banquets that featured the musics and dances of yesteryear (Gardner 1992: 24-26; Mackie 1993: 219; Price 1928). In these settings and others, such as past fur trade employee reunions (McKenzie 1921: 214), the Red River Jig became a particularly potent signifier of nineteenth century life. These groups' use of the Red River Jig accompanied a rather stilted view of Native peoples place in this past as captured in Elizabeth Price's 1928 newspaper article "Preserving the Red River Jig for Posterity." Here Price enthusiastically celebrated "the discovery" of the Kiplings, ambiguously referred to as "pioneers" and "natives," who were recruited to teach the Red River Jig music/dance to a mother-daughter piano/dance instruction team for the benefit of the Calgary Old Timers and their annual roundup celebrations. Overall, the article leaves the impression that the Kiplings' backgrounds and experiences are secondary to the grand goals of the McDonalds and the Calgary Old Timers' Association's preservation project.

Perhaps Joseph F. Dion's Métis dance troupe provided a small measure of alternative discourse to these sweeping narratives of frontier life. Already mentioned above, Dion had recorded Métis elders' recollections of nineteenth century fiddle dancing; these stories then become the fodder for later publications and radio broadcasts, as well as his introductions to dance exhibitions performed by a Métis troupe from St. Paul, Alberta during the 1930s. Dion was a Cree from the Kehewin reserve in Alberta; however, he had married a St. Albert Métis and had become active in the Alberta Métis political scene during the late 1920s, eventually becoming the president of the fledgling Metis 
Association of Alberta in 1932 (Dempsey 1979: vi; Holmes 1930: 273; Dobbin 1987: 63-64). Similar to the Old Timer's associations, Dion took a preservationist approach to representing past Métis life, evident in his detailed notes as well as the costumed appearance of the dance troupe. Nonetheless, Dion's goals were as much tied to the future acceptance and social advancement of Métis peoples in Canadian society as they were about nostalgically celebrating their past (Dempsey 1979: vi). ${ }^{2}$ It is difficult to see how an Alberta Métis political voice would come through in the settings in which this troupe performed, such as at Old Timer's events in Edmonton or the Calgary Canadian Pacific Railroad festival (see Henderson 2005 for more on this festival). Yet, the Canadian Geographical Journal photographed the Métis troupe at this Calgary festival, adding (albeit with a skeptical tone) the caption, "These descendants of Scottish and French fur traders and Indian mothers claim they are the only real Canadians" (Holmes 1930: 273).

During the 1940s and the 1950s the only sources I have located that mention the Red River Jig being performed in public exhibitions are those that mention the annual events sponsored by the Northern Alberta Pioneers' and Old Timers' Association (Dalheim and Kerr 1955: 19; Lunan 1979: 309). Perhaps the Red River Jig's absence in public settings was due to the pronounced shame and stigma associated with Native identity. When consulted about her childhood in the 1940s and 1950s, one of the informants related that her mother would only dance the Red River Jig for her privately, hiding these dance skills in other social dance situations so as not to signal her Native heritage. At the same time many other elder consultants fondly recalled small, local dance gatherings at which the Red River Jig was ubiquitous; and many local histories also point to the popularity of the Red River Jig in small community dance gatherings in Native settings throughout Alberta, such as on the provincially recognized Métis settlements that Dion had a hand in establishing (Federation of Metis Settlements 1979: 47; Frog Lake Community Club 1977: 171-2; Horstman and May 1982: 63; Hunt 1984: 312).

In the 1960s and 1970s the Red River Jig was again featured in more public settings, this phase also corresponding to the growth of

2. Dion's notes as well as photographs of this dance troupe are found in the Dion fonds (M331) at the Glenbow Archives. Some of these photographs may be seen by doing an on-line search at http://ww2.glenbow.org/search/ archivesPhotosSearch.aspx. 
Native political and cultural organizations and the movement of Native peoples into urban settings. In Edmonton, in addition to some Native political organizations becoming active again, such as the Metis Association of Alberta already mentioned (Meijer Drees 2002: 16066; Sawchuk 1998: 57-8), other organizations such as the Canadian Native Society formed in order to promote a more comfortable social scene for Native peoples in the city (Rowan n.d.). The Canadian Native Society sponsored monthly fiddle dances, and the proceeds from these dances went towards establishing the Canadian Native Friendship Centre, officially opening in 1962 (Rowan n.d.). Early on the Friendship Centre initiated a referral service for newcomers to the city, instructional and recreational programs, and a space for socializing. Saturday afternoons were set aside for children's dance instruction with a live fiddler and caller; Saturday evenings were for adult socializing, and dancing was a regular feature (Edmonton Native News 1964-69).

In October 1963, through the collaboration of several organizations including the Canadian Native Friendship Centre Association, "Alberta's First Native Festival of Music and Dance" featured vocal, guitar, fiddling, and dance competitions (the Reel of Eight, the Duck Dance, and the Red River Jig) at which contestants from Edmonton and many other places in Alberta displayed their talents (First Native Festival of Music and Dance 1963). Under the auspices of the Friendship Centre, this was the first of the many annual "All Native Festivals," and later festivals featured additional contest categories such as the Drops of Brandy, Reel of Four, and Square Dancing sets (Edmonton Native News November 1967, 1968). In 1971 the Canadian Native Friendship Centre Association acquired an old church, fondly remembered as "the old Friendship Centre," 3 that allowed for an expansion of services. During this period, people recalled attending the afternoon dance classes on the weekends or the evening social dances held in the church basement. They also related memories of the All Native Festival's evening Old Time dance after the day's competitions, some reminiscing about the perimeters of the dance floor lined with dancers from all over Alberta in a "Saskatchewan Circle" (see Table 1). Another consultant recounted learning his "first change" of fancy stepping to the Red River Jig at this evening Old Time dance.

3. The Friendship Centre moved from this building in the early 1990s to its current location on $101^{\text {st }}$ Street. 
Broadly speaking, the 1970 s also brought two related social movements connected to the political context of constitutional reform: the push towards promoting multiculturalism and the continued growth of Métis political organizations. This period encouraged already extant troupes and the formation of new ones; in Edmonton, Native dance

Table 1 Métis/Old Time Dance Domains (Edmonton, Alberta)

\begin{tabular}{|c|c|c|c|c|}
\hline & Domains & Dances & Activity & $\begin{array}{l}\text { Contains Jigging } \\
\text { Steps }\end{array}$ \\
\hline $\begin{array}{l}\mathrm{F} \\
\mathrm{r} \\
\mathrm{o} \\
\mathrm{m} \\
\mathrm{m} \\
\mathrm{m}\end{array}$ & $\begin{array}{l}\text { Traditionnal } \\
\text { Métis } \\
\text { Dances }\end{array}$ & $\begin{array}{l}\text { Rabbit Dance } \\
\text { Handkerchief Dance } \\
\text { Double Jig } \\
\text { Duck Dance } \\
\text { Red River Jig } \\
\text { Reel of Four } \\
\text { Reel of Eight } \\
\text { Drops of Brandy }\end{array}$ & $\begin{array}{l}- \\
-\mathrm{X} \\
\approx \mathrm{X} \\
+\mathrm{X} \\
+\mathrm{X} 0 \\
+\mathrm{X} \\
+\mathrm{X} \\
+\mathrm{X}\end{array}$ & $\begin{array}{l}\text { Unsure } \\
\text { Likely } \\
\text { Y } \\
\text { Y } \\
\text { Y } \\
\text { Y } \\
\text { Y } \\
\text { Y }\end{array}$ \\
\hline $\begin{array}{l}\mathrm{i} \\
\mathrm{t} \\
\mathrm{i} \\
\mathrm{o} \\
\mathrm{n} \\
\mathrm{a}\end{array}$ & Called Dances & $\begin{array}{l}\text { Saskatchewan Circle } \\
\text { Waltz Quadrille } \\
3 \text { changes of Square Dance sets } \\
2 \text { changes of Square Dance sets }\end{array}$ & $\begin{array}{l}\approx \\
\approx \\
\approx \\
+X 0\end{array}$ & $\begin{array}{l}\mathrm{Y} \\
\mathrm{N} \\
\mathrm{Y}^{*} \\
\mathrm{Y}^{* *}\end{array}$ \\
\hline $\begin{array}{l}\text { l } \\
\text { s } \\
\text { s }\end{array}$ & Show Dances & $\begin{array}{l}\text { Broom Dance } \\
\text { Sash or Belt Dance } \\
\text { Competitive Square Dancing } \\
\text { Orange Blossom Special }\end{array}$ & $\begin{array}{l}+X \\
+X \\
+X \\
+X\end{array}$ & $\begin{array}{l}\mathrm{Y} \\
\mathrm{Y} \\
\mathrm{Y} * * * \\
\mathrm{Y}\end{array}$ \\
\hline $\begin{array}{l}a \\
d \\
\text { i }\end{array}$ & $\begin{array}{l}\text { Side to Side } \\
\text { Dances }\end{array}$ & $\begin{array}{l}\text { Heel-Toe Polka } \\
\text { Sideways Polka } \\
\text { Schottisches } \\
\text { Butterfly dance }\end{array}$ & $\begin{array}{l}+0 \\
0 \\
0 \\
+\approx\end{array}$ & $\begin{array}{l}\text { Y during parts } \\
\text { Y } \\
\mathrm{N} \\
\text { Y during parts }\end{array}$ \\
\hline $\begin{array}{l}\text { n } \\
\text { a } \\
\text { l }\end{array}$ & Couples Dances & $\begin{array}{l}\text { Waltzes } \\
\text { The Seven Step } \\
\text { Two-Steps } \\
\text { Polkas } \\
\text { Foxtrots }\end{array}$ & $\begin{array}{l}0 \\
+0 \\
0 \\
0 \\
0\end{array}$ & $\begin{array}{l}\mathrm{N} \\
\mathrm{N} \\
\mathrm{N} \\
* * * * \\
\mathrm{~N}\end{array}$ \\
\hline
\end{tabular}

Activity Key: - only referred to; $\approx$ rare; + taught at EMCDS; $\mathrm{x}$ past exhibitions; $\mathrm{X}$ contemporary exhibitions; 0 contemporary social dance settings; *during third change/ breakdown; **during second change/ breakdown; *** during second change/ breakdown; ***** some may dance with jig steps. 
groups already participating in the All Native Festival had additional opportunities to perform in staged affairs showcasing Canada or Alberta's multicultural heritage. For example, one consultant related how, as a young teenager with a male partner, she represented the Métis by Red River Jigging in two such showcases. In the first, called "Alberta People, Alberta Culture," she recalled that Italians, French Canadians, Scots, Ukrainians, East Indians, and one powwow dancer for First Nations people were also featured (Loyer 2004). Rehearsing in the summer, the show eventually went on tour in southern Alberta, Manitoba and Nova Scotia. The second show was titled "Alberta Now and When" and incorporated the same kind of showcasing of individual dance cultures, but included a futuristic story line that brought all the dancers together in a choreographed finale. ${ }^{4}$ Although these large-scale traveling acts were short-lived, heritage events continue to feature Métis dancers (and the Red River Jig) such as the outdoor pavilion-style Edmonton Heritage Festival, which began in 1974 and continues today.

In this same period, Métis political organizations were promoting Métis history and their right to express their unique cultural heritage (Daniels 1979a, 1979b), their discourse corresponding with multiculturalism discourse already in play. In 1982, largely through the efforts of provincial Métis organizations and their national representative body the Native Council of Canada, Métis obtained recognition as Aboriginal in the Canadian Constitution. It is also in this period leading up to the 1980 s - a watershed period of social, cultural, and political recognition for Métis that largely continues today — that the Red River Jig began to be called the Métis National Anthem although this status has never been officially put in place (Chrétien 2002: 104). In Alberta, the Métis Association of Alberta (now the Métis Nation of Alberta) also sponsored Old Time dances at their "locals" (smaller political districts) as well as at their annual assemblies, events that also featured talent shows, fiddling and jigging contests, and exhibitions by dance troupes (Metis Newsletter 1970, 1978). Further, Alberta dance troupes began to travel to "Back to Batoche," a festival established in 1970 by

4. Both these shows were organized and directed by Gene Zwozdesky, who at the time worked for the Department of Alberta Culture and was the Director of the Alberta Cultural Heritage Foundation. Zwozdesky was a well-known proponent of Ukrainian cultural heritage specifically and multiculturalism more generally, and his influence in Alberta remains as he is an elected MLA who also sits on several community boards. 
the Saskatchewan Métis political organization (the Association for Metis and Non-Status Indians, now called the Métis Nation of Saskatchewan) that memorializes Louis Riel and his followers' last stand at the site of the 1885 Batoche battlefield.

Many of the networks of support that currently feature the Red River Jig were already foreshadowed. The formation of semi-professional dance troupes, first referenced in Dion's troupe and later in the groups involved with the Friendship Centre, has continued. Groups perform at some of the same events such as at the Edmonton Heritage Festival and Back to Batoche as well as at newly created events such as John Arcand's Fiddle Fest or Edmonton's Métis Fest, which began in the late 1990s and is seen by its organizers, in part, as a revival of the earlier annual All Native Festivals ${ }^{5}$. Instructional settings have continued, emphasizing the importance of certain dances such as the Red River Jig, which is seen as the quintessential form within the set of dances now performed as "Traditional Métis dances" (Table 1). The smaller, local gatherings some of my consultants nostalgically recalled have basically fallen out of practice. However, to some degree these kinds of settings are being indexed in the Old Time Dances often taking place in association with other events - family reunions, fiddle contests, festivals, CD-release concerts, and Jamborees.

It would be easy to mark a complete distinction between the earlier phases of the Red River Jig's practice in social dance situations versus its more recent practice in more exhibition or staged settings, a distinction made between informal and formal dance forms (Royce 2004: 164-165). As Royce wrote, "Dances that fall into the category of formal are those used explicitly as a symbol of identity on occasions when more than one cultural group interacts or when there is a desire to create a feeling of group solidarity even in the absence of outsiders" (2004: 164), a description that could easily apply to contemporary performance of the Red River Jig. Yet closely following the Red River Jig's history poses a difficulty in positioning its form/function as either informal/recreational or formal/symbolic throughout many periods of its practice.

5. This festival also coincides with Edmonton's Métis Week, officially established in 1996, and always falling during the week of the anniversary of Louis Riel's hanging (November 16, 1885). 
For one, it appears early on to be a dance used to show off individual skills, making it unique within the gamut of other social dances practiced during the late nineteenth century and into the mid-twentieth century. This significant aspect of the Red River Jig is seen in one Edmonton consultant's response to my question about why the Red River Jig was so special.

It was basically the only time that just two people were able to show what they can do. You see it was danced by a lady and a man, and they had steps that they... it was a type of a dance where the focus was actually on two people. Where the other dances, you know, Duck dance it was three couples, Saskatchewan Circle it was the whole hall, Square dances they could be anywhere up to 8 or 10 couples... there was no focus on individuals.... [With the Red River Jig] you have the opportunity to showcase your personal talent, where you don't in the other ones (Anderson 2000).

In addition, I already alluded to accounts relating the Red River Jig's popularity as a challenge dance between two men attempting to outdo each other in their abilities to execute numerous different steps (see also Dorion-Paquin and Smith 2002: 19). So perhaps it should be no surprise the Red River Jig has a relatively long history as an exhibition and contest dance since its function in social dance settings is somewhat similar. Secondly, it appears that for much of the twentieth century, exhibition and social dance situations existed simultaneously for dances now marked as traditional Métis - most especially the Red River Jig. In trying to complicate the marked distinction that folklorists and dance scholars have made between social dances and the "second existence" of such dances in exhibition and revival settings, Nahachewsky posited that some forms may experience a new beginning through revival settings while also continuing as they did before in other settings (2001: 20). I would argue that this aspect of simultaneity also applies to the Red River Jig as well as, for a period, most of the other dance forms now performed as "Traditional Métis dances" (Table 1).

Interestingly, Nahachewsky (2001: 20) used U.S. square dancing as an example of a form that was practiced in both "first existence" and "second existence" settings, square dancing being also an ubiquitous contest form at many Métis and First Nations events in Western Canada. Here is a dance form that has existed for many groups across North America as a social dance at the same time as it was being revived and codified by others in the U.S. beginning in the 1920s (Friedland 1998: 686-689). More recently, some First Nations and Métis square dance 
performers have become interested in maintaining the traditional aspects of square dancing in part because of their concern with the innovations that contest settings encourage. ${ }^{6}$

Different approaches in promoting the Red River Jig also show the multilevel aspects of display and revival in contemporary settings. The John Arcand Fiddle Fest's emphasis on promoting an attention to traditional steps and forms in its contest formats is in direct reaction to other contests. Thus, using Nahachewsky's terminology, the Fiddle Fest is exhibiting more "reflectiveness" than other settings in its approach to the Red River Jig, although I believe contemporary settings are all in all more consciously concerned with maintaining the Red River Jig as a cultural tradition that exhibits something intrinsic about Métis heritage than practitioners were during the nineteenth century. I recognize that there has ultimately been a shift in practice for those dances now marked as traditional Métis dances somewhat akin to the first and second existence phases Nahachewsky critically examines: most of these dances (except the Red River Jig) are now much less likely to appear in social dance settings as they are in staged settings. However, as previously pointed out, these dances did not shift from being social dances to dances marked as significant Métis heritage in a cut and dried manner; nor do contemporary festival settings function as exhibitory sites alone. During such festivals, I observed many people jigging beyond the stage in more informal settings such as in the evening Old Time dances during a rendition of the Red River Jig as well as in other dance forms such as the "Sideways Polka" or the "Heel and Toe Polka." Even in competitive settings, emcees will encourage jigging outside the staged competitions. For example, at the Edmonton Métis Fest in 2002, a highlight after the Saturday afternoon jigging contest occured when the main organizer encouraged volunteers, elders and eventually anyone so inclined to get up on the stage to show off their jigging skills.

6. Even within the sphere of Métis and First Nations square dancing in Western Canada, dance troupes emphasize different features in their revivalist interests. For example, the troupes from Alberta with whom I am the most familiar are trying to sustain the calling aspect of the tradition (and the forms associated with these calls) and see some of the other troupes (from Saskatchewan and Manitoba) as being non-traditional in the forms they use in contests. Yet some of the contests/troupes in Manitoba have maintained three parts in their sets the first change, second change, and third change/breakdown (Byron Dueck 2005), while in Edmonton, Alberta they now only use a first change and breakdown in their sets. 


\section{The Red River Jig's Dance Form}

The Red River Jig is danced to a tune by the same name, although the tune "Big John McNeil" is also popular in some settings. ${ }^{7}$ The overall pattern of the dance is simple: in the first part the dancer performs a "basic step," often referred to as "jigging"; and in the second part, when the tune moves into lower pitches, the dancer moves into a different set of steps that are markedly fancy — and these steps change every time at this same section in the tune. When the tune starts over, the dancer returns to basic stepping. The cue in the music for the new steps to begin as well as the entire second section itself may be referred to as "the change," while "changes" refer to complete executions of both parts. Thus, completing four changes would mean jigging interspersed with fancy steps four times. ${ }^{8}$

These shifts from basic to fancy stepping create a dramatic suspense since spectators have to wait to see what new fancy steps the dancer will attempt; and in a contest or exhibition a particularly exciting step will cause an audible stir (clapping and cheering) or an encouraging remark from the master of ceremonies. "The change" provides variability and the potential for virtuosity. In contests or exhibitions the number of changes is usually regulated at the onset, often only two or three changes and usually no more than four changes. In other circumstances, such as at Old Time dances, the fiddlers may repeat the Red River Jig enough times to allow jiggers to perform numerous changes, anywhere from five to fifteen renditions. Further, the legendary mythos of jiggers once knowing many more changes plays a part in contemporary efforts towards sustaining and revitalizing the "traditional steps."

Currently dancers usually perform the Red River Jig as a solo dance, whereas my consultants emphasized that in the past it was a dance for two performers. The couple would travel during their jigging at a certain

7. At a Red River Jig workshop at Emma Lake Fiddle Camp (2000), one of the teachers in the Frontier Fiddler's program in Northern Manitoba commented that First Nations groups would use this tune instead because of the Red River Jig's strong association with Métis nationalism. Big John McNeil is definitely a favorite for the "sideways polka" and for square dance breakdowns (at social dances and in competitions); and at Back to Batoche's evening dances, if Big John McNeil is played, some people will indeed step to it in the Red River Jig manner.

8. A consultant from Norway House, Manitoba told me that in his community they called these rounds instead of changes. 
distance from each other, moving in various patterns depending on regional conventions; and when the tune arrived at the second part, they would do the fancy stepping in place, usually facing each other. ${ }^{9}$ Although in most contemporary settings on the prairies jiggers no longer dance with partners, some jiggers maintain a traveling pattern when they are not executing the fancy steps. ${ }^{10}$ Most commonly, jiggers will move in rings of varying sizes before their fancy stepping. For example, at "Back to Batoche" many Red River Jig competitors move in a circular fashion on the large dance floor, while in other cases performers have opted to face the judges/audience continuously. In other contests, the stage further constrains this travelling, although some jiggers will travel in patterns within the available space.

Beyond watching the different changes and whether dancers stay with the fiddle's tempo (there is a tendency, for younger dancers especially, to dance quicker than the fiddle), other experienced dancers, musicians, and judges will listen/watch for the preciseness of the stepping ${ }^{11}$ and follow to see if the dancer shifts their movements at the correct moments. Shifting into "the change" at the proper place can be

9. Lederman described couples dancing the Red River Jig in the Ebb and Flow and Camperville communities in Manitoba in this fashion, "the couple circles... standing side by side and using a basic step. Starting with the woman, they take turns doing a fancy step... while the other partner continues the basic shuffle" (1986: 140). In Alberta, I have never seen this kind of turn taking nor did I see it mentioned in past documents. The couples competing at John Arcand's Fiddle Fest from 2002 to 2005 used this form: first jigging counterclockwise in a circle, the male directly opposite the female as if on the same diameter, then at the change, facing each other for their fancy stepping in place. In Alberta, at least three other couples forms have been in practice: 1) a straight line form where couples jigged forwards in a straight line while holding hands, turned back (and changed hands) towards their starting place, and at the change they would turn to face each other for the fancy stepping; 2) another circular form where the couples instead of facing each other and stepping in place during the change would continue around the circle during their fancy stepping; and 3) an "S-shaped" form where couples would turn in different directions and then loop around so that they would jig back towards their partner, stopping in place at the change while facing each other (see Quick 2008 for more details on these variations by region in Alberta).

10. Mishler documents the elaborate traveling done when Gwich'in performed the Red River Jig in couples (1993: 65-68), and these communities may have maintained these patterns.

11. As some point out, good stepping sounds like a horse galloping — you can both see and hear the preciseness of the stepping. 
quite difficult depending on what the new step is as well as on the dancer's familiarity with the particular version of the Red River Jig to which s/he is performing. As has been documented by the recent Drops of Brandy recording project (Dorion-Paquin et al. 2002) as well as by Lederman $(1986,1987)$ and Gibbons (1981), many versions of the Red River Jig tune exist. Furthermore, the different versions vary in the lengths of their first and second sections: the Red River Jig exhibits par excellence the now often cited feature of Métis fiddling - "crooked" tunes. Métis tunes or tunes altered into this aesthetic are known for their sections not lining up, or having asymmetric phrases due to added or dropped beats, especially at the beginnings and endings of sections (Gibbons 1981: 79-81; Lederman 1991: 42). Therefore, in order to stay with the fiddle during the Red River Jig, dancers must listen to the tune's contour, most especially the phrases that lead into the lower second section and back into the higher first section. Most fiddlers play a quick Red River Jig; executing the fancy steps is difficult in its own right in addition to having to listen for cues to move in and out of these steps.

\section{Learning to Jig}

I began attending dance classes at the Edmonton Métis Cultural Dance Society (EMCDS) twice a week in September of 2002. As I later learned, the EMCDS founding family, the Donalds, was also pivotal in the earlier days of the Canadian Native Friendship Centre's dance instruction and the All Native Festivals of the 1960s, 1970s and 1980s. ${ }^{12}$ In the EMCDS bi-weekly classes, I joined young beginners as well as more advanced young students, who in addition to the instructor served as models for the beginning dancers; the ages ranged from four year olds to young teens although the dance instructor would occasionally get watching parents (and grandparents) out of their seats to join in during specific dances. For contemporary students, video instruction may supplement their learning; instructional videos are available commercially and on the web, and a few students I met in class

12. The EMCDS formed out of the dance group that had been affiliated with the Friendship Centre, but in the 1990s they formed a society and later opened an instructional facility. For a period the EMCDS was the only group in Edmonton promoting these dances, although currently the Friendship Centre and other organizations offer Métis dance instruction. 
mentioned using videos at home when they practiced. Unlike the dance classes once housed at the "Old Friendship Centre" during the 1960s, 1970s, and 1980s, these classes used several revolving fiddle recordings (CDs and cassette tapes) instead of live fiddlers for musical accompaniment.

In our first few sessions as much as learning the patterns for specific dance forms (as seen in Table 1 above) learning "the basic step" was most emphasized. The quickest form of the basic step (actually a series of steps) is what is used in the first section of the Red River Jig; and as seen in Table 1, this stepping (or more commonly "jigging") recurs in the square dance breakdowns, the dances currently performed as "Traditional Métis," and many other dances associated with Old Time dance events. Table 1 represents the several domains of dance types that correspond, in part, to their associated values as representatives of Métis heritage; these are basically "folk" domains already in play, although the contents and even the larger categorical designations are quite fluid.

Coinciding with quicker tempi, jigging switches between the feet in a quick manner. For most of the Red River Jig's first section as well as breakdowns/reel tunes, two notes (usually transcribed as sixteenths in fiddle tunes) coincide with each step in the most basic form of jigging. This kind of stepping is rendered almost like a walking step, the fourth step sliding into the first of the next series of steps (see Figure 1). For many, this slide is more like a quick forward kick that then lands on the toes (especially when jigging in place). This step/kick can also vary significantly between jiggers, such as what part of the foot touches the floor: some jiggers may not even touch the floor, keeping their foot slightly aloft; while others may touch down with the toe, others at the ball of the foot, and others with the entire foot. At the EMCDS classes, the instructor and the other more advanced dancers use most of their foot while stepping, but for this step/kick they slide from their heels into a lift and then final tap on the front part of the foot. Some jiggers perform the step/kick movement with very little forward sliding so that it appears as a heel and then toe touch in place, while other jiggers stay primarily on the balls of their feet throughout so that the step/kick is then made as either a quick lift and or forward slide on their toes or a slight toe flick in the air. Further variation appears in emphasis: some spring their lower leg quite high behind the knee in preparation for 
step/kick, which makes their overall stepping appear quicker and higher off the ground, while others land their foot (or toes) more forcefully. All of these variations may come into play with experienced jiggers' mimicry of other jiggers' mannerisms.

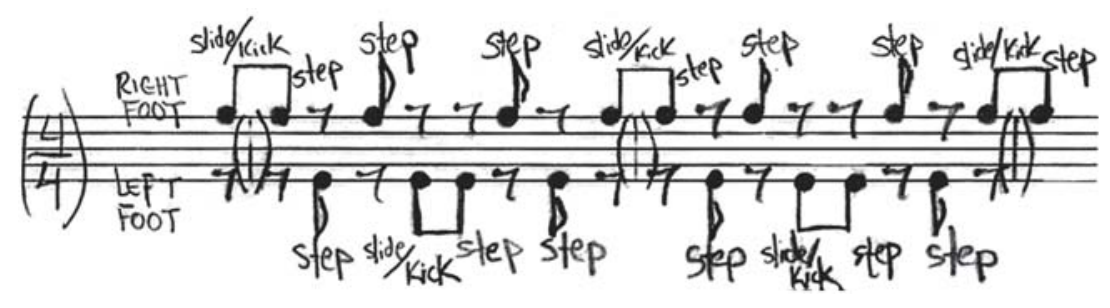

Figure 1. Basic Jigging Step.

Although the EMCDS taught jigging starting with the basic step in Figure 1, I noticed some of the advanced dancers in class and in competitions had a springier and quicker quality in their jigging, what one of the EMCDS dance instructors from Saskatchewan referred to as a "double step" or "double shuffle." Upon review of my video recordings, I realized they were doing a quick shuffle in their third step as well, which creates a faster sequence of steps (see Figure 2). This movement appears like a smaller, quicker repeat of the step/kick I described above, requiring additional hopping or pivoting of the other foot. For some, this hopping only coincides with certain steps, while others hop with both feet throughout their stepping. ${ }^{13}$ This quicker form of jigging is also what most competitive square dancers perform during the second changes and breakdowns in contemporary settings.

13. These figures should not be seen as prescriptive since there is considerable variation between jiggers and the amount of parallel pivoting/hopping from the other foot. Further, metric distinctions (duple vs. triple) nor first vs. second, third, or fourth beats should not be overemphasized since meters vary within many tunes and dancers are not really conscious of a sequencing of beats when matching their steps to the music. Byron Dueck's rhythmic diagram of the Red River Jig step (2004, see also 2005) as well as our subsequent conversations also contributed to my understanding of the variation between jigging steps (see also Lederman 1987, p. 17). 


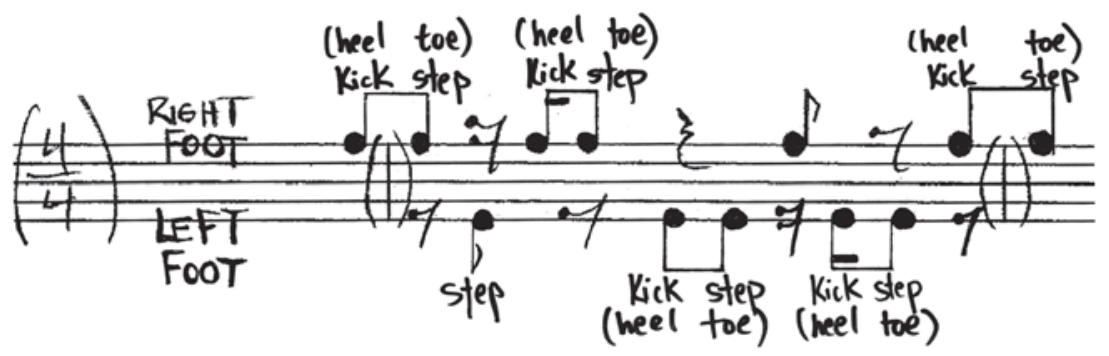

Figure 2. "Double Step" Jigging.

\section{Red River Jig Changes}

As mentioned, four changes by a particular jigger are usually the most audiences see during competitions; thus, many jiggers only have a few changes in their repertoire. At EMCDS, the instructor and the more advanced student jiggers were alternating between twelve to fourteen steps in class, some of these steps elaborations upon others. The EMCDS instructional video (2001) features five different steps, and different jiggers versions of a couple of steps are shown as well. The three steps during changes that I see repeated again and again by EMCDS dancers as well as by dancers in settings outside of Alberta are: 1) side-to-side alternating steps or what the narrator in the EMCDS video referred to as "the side to side" and "side shuffle"; 2) alternating heels in the front called "the heel and toe" in the EMCDS video; and 3) an alternating crossing over of one foot by the other with a toe tap, called a "heel and toe crossover" in this same video (Edmonton Métis Cultural Dance Society 2001). ${ }^{14}$

Nowadays, only more experienced dancers master more than ten changes. Yet evoking the legendary and spectacular quality of the Red River Jig, people recall witnessing or hearing about many more changes executed by dancers. I have heard the numbers thirty-one, forty, and even fifty-two mentioned for the number of changes good dancers once knew. Well-known Métis fiddler John Arcand recalls seeing his uncles

14. The names for these fancy steps during the changes are not consistent, if dancers even refer to them by a particular name. Some of these same steps also appear on the video "Steps in Time" (Gabriel Dumont Institute 1989) with different names such as "Double Jig Step" for the "side-to-side" on the EMCDS video. 
do fifty-two changes, and his personal mission has been to promote the revival of traditional steps at his annual Fiddle Fest near Saskatoon, Saskatchewan. Here the Red River Jigging competitions are not limited to a certain amount of changes; instead, competitors are encouraged to perform all the traditional steps they know. Those performers that complete the most variety of steps in the change section judged as traditional will win the competition. ${ }^{15}$

The greatest number of changes I have ever witnessed by a single jigger at one time has been at the John Arcand Fiddle Fest: in 2004, Raymond Shumi from Tisdale, Saskatchewan completed twenty-two changes; and in 2005 he completed twenty-one, winning the grand championship that year. Also in 2005, for the first time, two jiggers invoked their right to challenge the contest winner. Another revival of sorts, John Arcand established this challenge option as a bow to the past tradition of Red River jiggers challenging each other, the challenger executing the same steps as the winner until the winner ran out of steps. If the challenger kept up, then he would have to complete an additional step beyond those they both had executed to become the winner. ${ }^{16}$ In 2005 a female competitor and a male competitor challenged the winners, and during these challenges, they followed the circular pattern of travel jigging and then fancy stepping in place facing each other. During the lengthy women's challenge, although the original winner prevailed, the competitors went through twenty-four changes

15. Steps some jiggers and judges view as acceptable in other contexts are not acceptable here. Some of these ideals are spelled out in the contest rules, which are written in the program and announced during the contest: 1) no clickers allowed; 2) only traditional steps counted; 3) no foot or leg shaking; 4) duplicate steps will not be counted; and 5) a step on one foot must be repeated on the other. I also know from speaking to the Fiddle Fest organizers that generally high stepping is seen as less ideal. These ideals are often mentioned in informal conversations (with jiggers and others), and sometimes will be publicly invoked. An example is the story of how challenges in the past were determined by jiggers having to dance with a shot of whiskey placed on a saucer on top of these jiggers' heads: the winner was decided based on who spilled the least amount of whiskey (see also Dorion-Paquin and Smith 2002: 19).

16. Although both males and females compete (usually in separate competitions) in contests nowadays, most consultants imply that it was a male activity in the past as do historical sources (McKenzie 1921: 52; Dion 1979: 84). 
(at least one was repeated) before the challenger was unable to accurately render a step.

\section{Jigging Innovations, Hybridities, and Social Poetics}

At least two contemporary dance innovations feature Red River Jigging. The Orange Blossom Special (named after the fiddle tune that accompanies the dance) was created by one of the EMCDS instructors (Brent Potskin) as both a teaching tool and a showpiece; it is always described as a show dance - not one of the "traditional Métis dances." Because fiddlers emphasize virtuosic bow crossings and accelerating tempi when playing the Orange Blossom Special, jiggers must closely follow the tempo while also listening to shifts in the tune that then cue them to change their stepping patterns. Once dancers have mastered the jigging and the fancy steps to go along with these different changes (and the speed that is required to execute them), the Orange Blossom Special is quite a show, although the familiarity that most audiences have with this tune also contributes to its popularity. I have seen several EMCDS students (past and current, singly and in groups) request this tune in order to show off their skills in both staged and in more informal settings.

Often featured alongside Red River Jig contests are Square Dancing contests at Métis and First Nations events. Competitive square dance troupes use four couples and the stepping associated with traditional square dancing; however, some groups are quite innovative in their routines, many only alluding to the dance patterns of traditional square dancing. One recent innovation incorporates Red River Jigging steps within the breakdown section. In 2004 at Back to Batoche, I witnessed two such groups, one an adult group from Manitoba and the other a junior group from Belcourt, North Dakota, incorporating Red River Jig steps into their Square Dance routines. These two groups also used the same format in their musical accompaniment: starting with a few renditions of the Red River Jig and then shifting to Big John McNeil. During the Red River Jig section, dancers faced the audience, each male and female dancer moving as an individual between the jigging steps and the fancy steps. The junior group traveled during the A part of the Red River Jig (basically rotating but maintaining the same formation), while the adult group also traveled during the B part (during their fancy steps) in order to move into new and elaborate formations. 
For both groups adding the Red River Jig into their routine emphasized their precision stepping since their clickers sounded in unison with the different rhythms of the changing steps. When the musicians and dancers moved into the Big John McNeil section, they then began to utilize the male-female dance patterns such as swings and promenades.

This is just one example of mixing the elements from the Red River Jig form with other dance forms/styles to create new layers of "hybridities." In the competitive square dancing case, this mixing exists mainly for contest or exhibition settings. In other cases, I have seen younger jiggers allude to other dance stylistics such as powwow or hip-hop dancing, most especially during their fancy stepping in the B section of their Red River Jigging.

In addition to these new "hybrid" forms, jigging appears in other performative circumstances. For example, Aboriginal comedians may jig as a humorous antic or use the entire Red River Jig as a template for more formalized jokes. For example, at the 2002 Métis Fest in Edmonton, the emcee for an evening gala, First Nations (Cree) comedian Don Burnstick, teased one of the main organizers about carrying a purse after he had walked away from the stage area. At first he joked, "It takes a real man to carry a purse," and then mimicked him by walking across the stage in a super-feminized manner. He then revised his roleplaying with, "Oh I forgot, he's Métis!” and then jigged in an exaggerated and super-feminized manner across the stage.

In keeping with Herzfeld's proposal for social poetics to encompass multiple sites connecting the "little poetics of everyday interaction with the grand dramas of official pomp and historiography to break down illusions of scale" (2005: 26), I view the various performance sites referencing the Red River Jig as potential signifiers of multiple narratives. So, while jigging has definitely become an iconic representation of Métis heritage (one example showing up in the Batoche musical where a jigging buffalo appears in a song about nineteenth century prairie life), individual jiggers also bring forth the ambiguities of these essentialisms in their performances as well as allude to many other experiences. For example, during a break between competitions at John Arcand's Fiddle Fest in 2005, First Nations (Cree) performer-comedian Winston Wuttunee performed a series of Red River Jig skits with live fiddle accompaniment. Based on characters such as "Shy Man Jig," "RCMP Jig," "Tough Man Jig," and "Missionary Jig," he went through at least 
one change of the Red River Jig to exhibit the noticeable alterations based on the character at hand. During the "Shy Man Jig," he danced somewhat hunched over, looking mostly at his feet and occasionally glancing up in a cowering manner, all the while dancing in tiny steps; while in "Tough Man Jig", he pushed his chest out, widened his stance, and forcefully covered more ground. During his "RCMP Jig" (Royal Canadian Mounted Police), he added arm swinging that mimicked the forceful use of a baton, a not-so-veiled commentary perhaps reflecting how he (and other Native peoples) views the RCMP as violent and intrusive.

As Herzfeld emphasizes, social actors perform and "deform" through their strategic use of essentialisms. Further, I would argue that their performances build layer upon layer of performative experiences that even in the most formalized and staged settings emerge through social experiences. Herzfeld contends that focusing on representations of iconic cultural homogeneity runs the risk of flattening out on-the-ground experiences: "the analytic challenge is to reverse the process, to see what indexical social ploys lurk behind the seemingly imperturbable iconicities of an officially unified culture" (30). Linked together by a well-known dance form in Aboriginal communities, these jigging gestures do not simply speak to a timeless Métis cultural heritage. Contemporary jiggers are indeed heralded as iconic signs of such a narrative, but they also bring forth the ambiguities of these essentialisms in their performances. One young Red River jigger pointedly merges one tradition (jigging) with another (powwow dancing), a fusion that some say already exists (although less blatantly than some performers currently mark), while another merges jigging with hip-hop as a signal to his generation's form expression. In the same span of his use of jigging as a quintessentially Métis practice, comedian Don Burnstick points to First Nations' interlopers (including himself) at a Métis celebration. Because the Red River Jig has for so long been a highlight at social dances and exhibitions, it brings with it multiple levels of appreciation and meaning. And while it has become iconic of Métis heritage and a Métis national identity, its performances emerge as indexes to social interactions and points of view not necessarily in line with a fixed national narrative of Métis identity. 


\section{References}

Anderson, Gilbert. 2000. Interview by Sarah Quick. Edmonton, Alberta, July 10 .

Begg, Alexander. 1871. Dot It Down: a Story of Life in the NorthWest.Toronto: Hunter, Rose \& Company.

Chrétien, Annette. 2002. "Under the Double Eagle": From Military March to Métis Miziksharing. The World of Music 44(1): 89-124. Dalheim, K. and M. Kerr, eds. 1955. Calahoo Trails: A History of Calahoo, Granger, Speldhurst, Noyes Crossing, East Bibly, Green Willow, 18421955. Calahoo (AB): Calahoo Women's Institute.

Daniels, Harry. 1979a. We are the New Nation: The Métis and National Native Policy. Ottawa: Native Council of Canada.

- 1979b. Declaration of Métis and Indian rights. Ottawa: Native Council of Canada.

Dempsey, Hugh. 1979. "Introduction". In Joseph F. Dion and Hugh Dempsey, eds., My Tribe, the Crees: v-viii. Calgary: Glenbow Museum.

Dion, Joseph F. 1915. Indian and Halfbreed-Old Time Stories. Unpublished handwritten notes. Dion fonds, M331/30 Glenbow Archives.

- 1979. My Tribe, the Crees. Calgary: Glenbow Museum.

Dobbin, Murray. 1987 [1981]. The One-and-a-Half men: The story of Jim Brady and Malcolm Norris, Metis Patriots of the Twentieth century. Regina: Gabriel Dumont Institute of Native Studies and Applied Research.

Dorion-Paquin, Leah and Lyndon Smith. 2002. "The History of Métis Fiddling”. In Drops of Brandy: An Anthology of Métis Music. Saskatoon: Gabriel Dumont Institute.

Dueck, Byron. 2004. "Metrical Regularity and Irregularity in the Red River Jig". Moving Boundaries: The Symbiotic Relationship between Music and Dance, Society for Ethnomusicology Pre-Conference Symposium. Tucson, Arizona, November 2004.

2005. Festival of Nations: First Nations and Metis Music and Dance in Public Performance. Unpublished dissertation, Chicago, University of Chicago Press.

Edmonton Métis Cultural Dance Society. 2001. EMCDS Basic Steps, video. Edmonton: Edmonton Métis Cultural Dance Society.

Edmonton Native News. 1964-9. Canadian Native Friendship Centre Newsletter, Reta Rowan fonds, 17/1/1-29, University of Alberta Archives.

Federation of Metis Settlements. 1979. East Prairie Métis, 1939-1979: 40 Years of determination. Edmonton: Federation of Métis Settlements. 
First Native Festival of Music and Dance. 1963. Unpublished organizational notes and program. J. D. Sturrock fonds, 84.28/7, Provincial Archives of Alberta.

Frog Lake Community Club. 1977. The Land of Red and White. Heinsburg (AB): Frog Lake Community Club.

Gabriel Dumont Institute. 1989. Steps in Time: Metis Dances.Video, Saskatoon: A Birdsong Communications Production.

Gardner, Beeth. 1992. Edmonton's Musical Life: 1892-1930. Edmonton: Fort Edmonton Park.

Gibbons, Roy W. 1981. Folk Fiddling in Canada, A Sampling. Ottawa: National Museums of Canada.

Henderson, Stuart. 2005. "While there is Still Time...: J. Murray Gibbon and the Spectacle of Difference in Three CPR Folk Festivals, 19281931". Journal of Canadian Studies 31(1): 139-74.

Herzfeld, Michael. 2005. Cultural Intimacy: Social Poetics in the NationState, second edition. New York: Routledge.

Holmes, Clara. 1930. "The Great West Festival at Calgary". Canadian Geographical Journal 1(3): 269-75.

Horstman, L. and D. May, eds. 1982. Tired of Rambling: A History of Fishing Lake Métis Settlement. Edmonton: Alberta Federation of Metis Settlement Associations, Friesen Printers.

Hunt, Katherine. 1984. Peace River Remembers: Peace River, Alberta, and Adjacent Districts. Peace River: Sir Alexander Mackenzie Historical Society.

Kurath, Gertrude. 1957. "Dance-Music Interdependence." Ethnomusicology 1(10): 8-11.

Lederman, Anne. 1986. "Old Native and Metis Fiddling in Two Manitoba Communities: Camperville and Ebb and Flow". M.A. Thesis, York University, Toronto.

. 1987. "Old Native and Metis Fiddling in Manitoba", vols. 1 and 2. LP and Cassette, Toronto: Falcon (FP - 187 and 287).

___ 1991[1988]. "Old Indian and Métis Fiddling in Manitoba: Origins, Structure, and Question of Syncretism". Canadian Folk Music Journal 19: 42.

Loyer, Celina. 2004. Interview by Sarah Quick. Calahoo, Alberta, August 4.

Lunan, Esther, ed. 1979. As the Roots Grow: The History of Spruce Grove and District. Spruce Grove: Spruce Grove Public Library.

Mackie, James A. N. 1993. History of the Society. Pioneer Families of Southern Alberta. Calgary: Southern Alberta Pioneers and their Descendants. 
Mair, Charles. 1908. Through the Mackenzie Basin: a Narrative of the Athabasca and Peace River Treaty Expedition of 1899. Toronto: William Briggs.

McKenzie, N.M.W.J. 1921. The Men of the Hudson's Bay Company. Fort William: Three Journal Presses.

Meijer Drees, Laurie. 2002. The Indian Association of Alberta: A History of Political Action. Vancouver: University of British Columbia Press. Metis Newsletter 1970, April 25 and July 1978. In Metis Association of Alberta fonds, M 4755/1515, Glenbow Archives, Calgary.

Mishler, Craig. 1993. The Crooked Stovepipe: Athapaskan Fiddle Music and Square Dancing in Northeast Alaska and Northwest Canada. Urbana: University of Illinois Press.

Nahachewsky, Andriy. 2001. "Once Again: On the Concept of 'Second Existence' Folk Dance”. Yearbook for Traditional Music 33: 17-28.

Ness, Sally. 1987. The Sinulog dancing of Cebu City, Philippines: A Semeiotic Analysis. Unpublished dissertation, University of Washington, Seattle.

Podruchny, Carolyn. 2006. Making the Voyageur World: Travelers and Traders in the North American Fur Trade. Lincoln: University of Nebraska Press.

Price, Elizabeth B. 1928. "Preserving the Red River Jig for Posterity". Toronto Star Weekly, April 7. (Elizabeth Bailey Price Newspaper Clippings M1002, Glenbow Archives).

Quick, Sarah. 2008. Performing Heritage: Métis Music, Dance and Identity in a Multicultural State. Unpublished dissertation, Indiana University, Bloomington.

Randall, Walter H. 1942. "Genthon the Fiddler". The Beaver (December): 15-17.

Rowan, Reta N.d. "Organizational reports of the Canadian Native Society and the Canadian Native Friendship Centre", Reta Rowan fonds, 17/1/1-29, University of Alberta Archives.

Royce, Anya. 2002 [1977]. The Anthropology of Dance. Hampton, Alton: Dance Books, Ltd.

Sawchuk, Joe. 1998. The Dynamics of Native Politics: The Alberta Metis Experience. Saskatoon: Purich Publishers.

Simpson, Sir George. 1938. Journal of Occurrences in the Athabasca Department: 1820 and 1821, and Report, vol.1 (E.E. Rich ed.). Toronto: Champlain Society for the Hudson's Bay Record Society. Steele, Samuel. 1915. Forty Years in Canada: Reminiscences of the Great North-West (Mollie Glenn Niblett ed.). London: H. Jenkins. 
Turino, Thomas. 1999. "Signs of Imagination, Identity, and Experience: A Peircian Semiotic Theory for Music". Ethnomusicology 43(2): 221255.

Wolf, Richard. 2006. "The poetics of 'Sufi' Practice: Drumming, Dancing, and Complex Agency at Madho Husain (and Beyond)". American Ethnologist 33 (2): 246-265. 
